\title{
TWO OLD UIGUR FRAGMENTS FROM DUNHUANG CONNECTED WITH THE PURE LAND BELIEF
}

\author{
ZHANG TIESHAN-PETER ZIEME \\ Academy for Research on Chinese Ethnic Minority Languages, Minzu University of China \\ 27 Zhongguancun South Avenue Haidian District, Beijing,100081, P. R. China \\ e-mail: zhangtieshan@sina.com \\ 16816 Neuruppin, Schinkelstr. 12, Germany \\ e-mail: ziemepet@gmail.com
}

In this paper the authors edit two Old Uigur fragments that have recently become accessible from Dunhuang. The first is part of a poem on the famous story of King Bimbasāra and his wife Vaidehī that was popular in Pure Land Buddhism. The second is a kind of a commentary that uses Chinese phrases in original Chinese script.

Key words: Old Uigur, Buddhist literature, Pure Land, commentary, Chinese phrases.

\section{A Poem on Amitābha}

The famous emotional story of Vaidehī, the wife of King Bimbasāra, was again and again a topic of inspiration for artists and literati. ${ }^{1}$ It might suffice to remind here of the prologue in the 觀無量壽經 Guanwuliangshoujing (T.XII.365). The text of this apocryphal sūtra was translated from Chinese into Old Uigur not only in prose $\mathrm{Ku}-$ dara 1979; Zieme 1982), but also newly arranged in alliteration verses and masterfully printed during the Yuan period (Zieme-Kudara 1985). The book also starts with the Vaidehī story (Zieme-Kudara 1985, p. 80, 1. 16) like this new manuscript, but the leaf is clearly the work of a different author. Whether one can find any connections between the two versions is a question which cannot be resolved now.

The leaf of a stitched booklet we are going to edit here belongs to the manuscript collection of the Dunhuang Academy, it bears the signature D.0019 (52.35.20) (see Figures 1 and 2). The size of the fragment is $7.5 \times 11.5 \mathrm{~cm}$. Since the page number

${ }^{1}$ The origin and composition of this story used in the prologue to the Guanwuliangshouhing were treated by many scholars, see Silk (1997); for artistic presentation compare i. a. Yamabe (1999, 2012). 
on the margin of the verso side is preserved, one can reconstruct the beginning of the booklet, but how many pages followed remains unclear.

Leaf 1 (missing)

If one counts 7 lines on each side of a leaf, one can estimate that the first three lines on page 1 were preserved for the title, followed by probably three stanzas of each 4 lines.

Leaf 2 with the leaf number $i k i$ "two". The first line on the first page of leaf 2 is the fourth line of stanza III.

The end of a stanza is marked by a four hooks sign. The script is very clear and resembles other examples used in the Yuan period. To give a precise date is impossible.

\section{Transcription of the text}

Recto

Stanza IIId

01 asig tusu k1lur ugur-ta ::

Stanza IV ${ }^{2}$

02 ačatašatru ${ }^{3}$ han-nı̀ atasi $^{4} \ldots .$.

03 ayaguluk bimbasare ${ }^{5}$ elig-kä ..

04 anas1 vaidehi ${ }^{6}$ hatun-ka ..

05 alku kamag terin-kä kuvrag-ka ::

Stanza $\mathrm{V}^{7}$

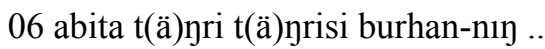

07 artokrak mäyi-lig uluš-1n ..

\section{Verso}

08 adırtl(1)g körkitü ${ }^{8}$ közündürü .. ..

09 antag tep inčä y(a)rlıkadııız ::

${ }^{2}$ Zieme-Kudara (1985, p. 80, 11. 13-16): [anta] basa bir tušta / ačagarh al(1)g balıkta / [ačata]šaturu elignin / anası vaidehi [v'ytyq y] hatunka.

\footnotetext{
3 ' 'č' d's't'rw.

4 " d'sy.
}

${ }^{5}$ The name is also known as Bimbisāra, but the Old Uigur form is derived from Bimbasāra. For Bimbasare cf. Zieme (2013).

${ }^{6} v^{\prime}$ ytyq y.

${ }^{7}$ Zieme-Kudara (1985, p. 80, 11. 17-20): [a]bita t(ä)yri burhanıg / artokrak mänilig ulušug / adırtlıg körkitü y(a)rlıkap / ača adıra nomlamıš.

${ }^{8}$ kwyrkydw. 


\section{Stanza VI}

10 kenki beš čöpdik üd-täki ..

11 kim kayu kiši yalanok oglanı ..

12 kkir-siz arı uluš-ta tuggalı ..

13 kertgünč taplag-ları bolsar-lar ::

Stanza VII

14 kolu-suz y(a)ruk-lug burhan-nı ..

\section{Translation}

\section{IIId}

$[\ldots]$

At a time [when (you, the Buddha) on the pure mountain Gṛdhrakūta] were making vantage and benefit [to the vaineyika beings having reasons (of good deeds)],

IVa-d

to King Bimbasāra -

the father of Lord Ajātaśatru -,

to his mother Lady Vaidehī,

to the whole community,

$\mathrm{Va}-\mathrm{d}$

you deigned to show and make appear

distinctly

the realm of utmost bliss (i.e. Sukhāvatī)

of Amitābha, the god of gods.

VIa-d

Whoever of the sons of human beings in the later period of the five impurities ${ }^{9}$

has in belief the wish

to be born in the stainless pure realm,

VIIa

[the word] of the Buddha 'Infinite Light' 10

(...)

\footnotetext{
${ }^{9}$ Usually the texts use čöpik.

10 "Infinite Light" is the translation of Amitābha.
} 


\section{Notes}

The text of this poem is partly known also from the manuscript U 5369 (T I 578) (BT.XIII.7). Here is a comparison of both versions:

01 asig tusu k1lur ugur-ta ::

02 ačatašatru han-nı̣ atas1 ....

03 ayaguluk bimbasare elig-kä ..

04 anası vaidehi hatun-ka ..

05 alku kamag terin-kä kuvrag-ka ::
BT.XIII.7

arig gadirakud ol tagta

avantlig vaineke tınl(1)glarka

asig tusu kılur ugurta

ačadašaturu hannıy atası

ayaguluk bimbasare eligkä

anası vudeh hatunka

a[lk]u kamag terinkä kuvragka.

artokrak mänilig uluš "Realm of utmost bliss" is one of the compounds of translating Sanskrit sukhāvatī (UWN II, 2, pp. 51-52). Accordingly, it seems better to reconstruct in the Avalokitśvara praise the verse BT.XIII.20.24 in the same way:

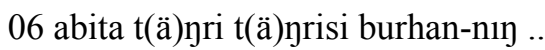

07 artokrak mäni-lig uluš-1n ..

08 adırtl(1)g körkitü ${ }^{11}$ közündürü ... ..

09 antag tep inčä y(a)rlıkadııız :: amita-aba burhanı

[a ] töpötä eltinür

[artokr]ak mänilig ulušug

[adırt]lıg munta ok körkitür.

\section{vaidehi //vudeh}

The name of the protagonist is the queen Vaidehī (cf. Zieme 2013, pp. 28-29; Wilkens 2017, pp. 215-216 [12v27]). The Dunhuang manuscript has the correct form vaidehi hatun, while one sees vudeh hatun ${ }^{12}$ in the manuscript of BT.XIII.7. The latter spelling is so far unexplained. The fragment U 2084 of the Berlin Collection, which is part of the prose translation of the Guanjing, has in recto 5 [... vaide]h hatun ${ }^{13}$ translating 佛告阿難及韋提希 “The Buddha said to Ānanda and Vaidehï” (T.XII.365c15).

\section{A Commentarial Text}

The leaf with the shelf number D.0590 (54.1.272) (see Figure 3) has a size of $14 \times 23$ $\mathrm{cm}$, it is part of a manuscript. The text is written on one side of the leaf. Since it definitely belongs to a pustaka shape manuscript with a typical pustaka hole extending from 1.4 to 1 . 7 , one has to assume that two sheets of paper were pasted together.

\footnotetext{
${ }^{11}$ kwyrkydw.

12 vwdyä q'dwn.

13 ...q $\ddot{q}^{\prime}$ twn.
} 
In the course of time one layer became detached and was lost. The Chinese quotations on 11.14 and 16 are written in red ink.

The Chinese quotations are taken from the $k i m k o k i^{14}<$ 金剛經 Jin'gangjing which is the standard short title of the Vajracchedikāsütra derived from its Chinese rendering as used in the commentary. The exact parallel is not found in the normal Chinese translations of the sūtra, only in the Fu Dashi verse commentary based on this sūtra (T.LXXXV.2732). This shows again the popularity of the Fu Dashi text among Uigur Buddhists.

The text of the leaf refers to the Pure Land, but this does not mean that the whole commentary can be related to the Pure Land Buddhism. Similar manuscripts have to be taken into account, too. One other fragment from the same manuscript 北大附 T3 was edited by A. Yakup in which a quotation is given from the Suvarnaprabhäsasūtra (Yakup 2015). As shown before, it is unlikely that the manuscript is a commentary to that sūtra (Zieme 2015). A further fragment from the same manuscript is 附 T2 which has the title and page number on its verso: šuntsi bir “顺次 shunci, one [first leaf]". Other leaves of similar manuscripts are known from the Collection in Berlin (Zieme 2015). ${ }^{15}$

\section{Transcription of the text}

01 inčip yänä bo nomlug tilgän

02 ävirgäli ötünmäk alku-nuy

03 asig-lig-1na tiltag bolmak

04 -tın yeg adrok ärsär

05 ymä inčip

06 yänä munta

07 ačınu yadınu

08 kšanti k1lmak burhan

09 -lar uluš-1n ukmak-nın

10 tıltag-1 ärür .. nätägin tep

11 tesär .. k(a)ltı bo sav-nın

12 tiltag-inta kimkoki sudur

13 -ta šlok-ta sözlämiši

14 bar 除心意地 ${ }^{16}$ aritsar

15 sipirsär köyül-nüy tarılag

16 yer-[in ...] 名爲淨土因

17 [atı] bolur .. burhan-lar uluš

18 -in etm[äk ...]

${ }^{14}$ kymqwky.

${ }^{15} \mathrm{P}$. Zieme's statement that the Beijing and Berlin leaves belong to the same manuscript is wrong. Although they are parts of the same text, the fragments stem from two different manuscripts. In an earlier paper P. Zieme edited the Suvarnaprabhāsasūtra quotation of the Beijing manuscript, some of his readings differ from those of A. Yakup (see Zieme 2014, p. 403, fn. 13).

${ }^{16}$ The first Chinese character 掃 is missing! 


\section{Translation}

As again the humbly turning of the dharma wheel is better and superior than being the reason for the welfare of all (people), just acknowledging and confessing (sins) is the reason for understanding the Buddha land. Thus as reason of this saying there is one śloka in the Vajracchedikāsütra which says: "if one purifies and cleans the citta field, it is like creating the Pure Land."

\section{Notes}

The Chinese quotation occurs in T.LXXXV.2732.3c28: 掃除心意地 名爲淨土因. It is part of the Fu Dashi (Maitreya) ślokas based on $\S 10 \mathrm{~b}$ of T.VIII.235.749c18-19 須菩提於意云何菩薩莊嚴佛土不不也世尊 “The Lord said, “Any bodhisattva, Subhūti, who says 'I will make the dispositions of a field perfect!' would be telling a lie.","17

It is translated into Old Uigur literally for the first verse, but more freely for the second one:

$\begin{array}{llll}\text { <掃> } & \text { 除 } & \text { 心意 } & \text { 地 } \\ \text { arıtsar } & \text { sipirsär } & \text { köyülnün } & \text { tarıglag yer[in] } \\ \text { 名 } & \text { 営 } & \text { 淨土 } & \text { 因 } \\ \text { [at1] } & \text { bolur } & \text { burhanlar ulušın } & \text { etm[äk]. }\end{array}$

The text U 3352 (BT.XXVIII.text B) has some interesting variants. For comparison we quote from Yakup's (2010) edition:

sipirsär arıtsar k[önülnün tarıglag yerin]

atı bolur burhanlar [ulušın etmäk : ${ }^{18}$

This clearly shows that the translation of the Dunhuang manuscript was made independently, unless it was the intention of the composer to present a better or a corrected version. But comparing both versions, one can hardly say which version can be regarded as more truthful to the original text.

Here, one observes that the order of the members of the biverb artt- sipir-can change to sipir-artt-. It is an interesting topic for the research of biverbs and binoms whether and how much the members can change freely or not.

From a Buddhological point of view it is worth noting that Chinese jingtu "Pure Land" was understood as a more general term "Buddha Land". This is reasonable as these terms can be used for expressing the same idea.

In both versions Chinese 因 yin "cause, reason" is translated by etmäk, the verbal noun from et- "to create, to decorate" etc.

\footnotetext{
${ }^{17}$ All quoted from the TLB database (in Bibliotheca Polyglotta).

${ }^{18}$ For the emendations A. Yakup follows the parallel text U 3214 recto 1-2 (BT.XXVIII.C224225).
} 


\section{References}

BT $=$ Berliner Turfantexte.

Digital Dictionary of Buddhism (Charles Muller; DDB). http://www.buddhism-dict.net/ddb/

Erdal, M. (1991): Old Turkic Word Formation. Wiesbaden, Harrassowitz (OTWF).

Kudara, K. (1979): Kanmuryōjukyō - Uiguru-yaku danpen shūtei 百済康義, 観無量寿経 一ウイ グル訳断片修訂 [Guan jing - critique of an Uigur fragment of the Guan wu-liang-shou jing -]. Bukkyōgaku kenkyū 仏教学研究 Vol. 35, pp. 33-56.

OTWF $=$ Erdal $(1991)$

Röhrborn, K. (2017): Uigurisches Wörterbuch. Sprachmaterial der vorislamischen türkischen Texte aus Zentralasien - Neubearbeitung - II. Nomina - Pronomina - Partikeln. Band II: ašäžük. Stuttgart, Steiner Verlag (UWN).

Silk, J. (1997): The Composition of the Guan wuliangshoufo-jing: Some Buddhist and Jaina Parallels to its Narrative Frame. Journal of Indian Philosophy Vol. 25, No. 2, pp. 181-256.

TLB $=$ THESAURUS LITERATURAE BUDDHICAE https://www2.hf.uio.no/polyglotta/index. php?page=library\&bid=2. Retrieved: 26.07.2018.

UWN = Röhrborn (2017)

Wilkens, J. (2017): The Old Uyghur Translation of the Bieyi za ahanjing (1935.52.0012-0015). In: Kasai, Yukiyo-Raschmann, Simone-Christiane-Wahlquist, Håkan-Zieme, Peter (eds): The Old Uyghur Agama Fragments Preserved in the Sven Hedin Collection. StockholmTurnhout, Brepols Publishers (Silk Road Studies 15), pp. 197-280.

Yakup, A. (2010): Prajñāpāramitā Literature in Old Uyghur. Turnhout, Brepols Publishers (Berliner Turfantexte [BT] XXVIIII).

Yakup, A. A. (2015): Chinese-Uyghur Bilingual Fragment of the Altun Yaruk Sudur. In: Kutadgu Nom Bitig. Festschrift für Jens Peter Laut zum 60. Geburtstag. Wiesbaden, Harrassowitz, pp. 629-637.

Yamabe, N. (1999): An Examination of the Mural Paintings of Toyok Cave 20 in Conjunction with the Origin of the Amitayus Visualization Sutra. Orientations Vol. 30, No. 4, pp. 38-44.

Yamabe, N. (2012): A Comparison of the Transformation Tableaux of the Amitāyus Visualization Sūtra and of the Favor Repayment Sütra. In: Ven. Dhammasami, Khammai-Willemen, Charles (eds): Buddhist Meditation: Texts, Tradition and Practice. Mumbai-New Delhi, Somaiya Publications Pvt. Ltd., pp. 293-416+15 figures.

Zieme, P. (1982): A New Fragment of the Uigur Guanwuliangshoujing. Ryūkokudaigaku Bukkyōbunka Kenkyūsho Kiyo Vol. 20, pp. 20-29.

Zieme, P. (1985): Buddhistische Stabreimdichtungen der Uiguren. Berlin, Akademie Verlag (Berliner Turfantexte [BT] XIII).

Zieme, P. (2013): "Toyın körklüg”. An Old Uigur Buddha Poem. Studies on the Inner Asian Languages Vol. 28, pp. 7-37.

Zieme, P. (2014): Collecting of the Buddhist Scriptures: Notes on Old Uigur "Annals". Annual Report of The International Research Institute for Advanced Buddhology at Soka University for the Academic Year 2013 [= ARIRIAB], Vol. 17, pp. 401-422.

Zieme, P. (2015): Anuloma und Pratiloma im altuigurischen Buddhismus. In: academia.edu (November 2015).

Zieme, P. - Kudara, K. (1985): Uigurugo no Kanmuryōjukyō. Guanwuliangshoujing in Uigur. Kyoto, Nagata Bunshōdō. 


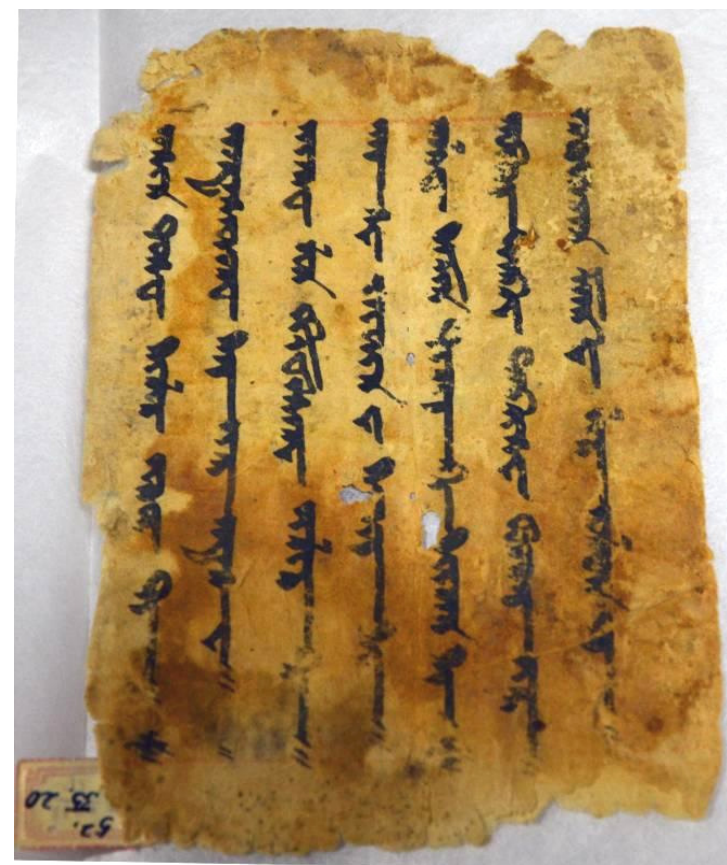

Figure 1. D.0019 (52.35.20). Recto

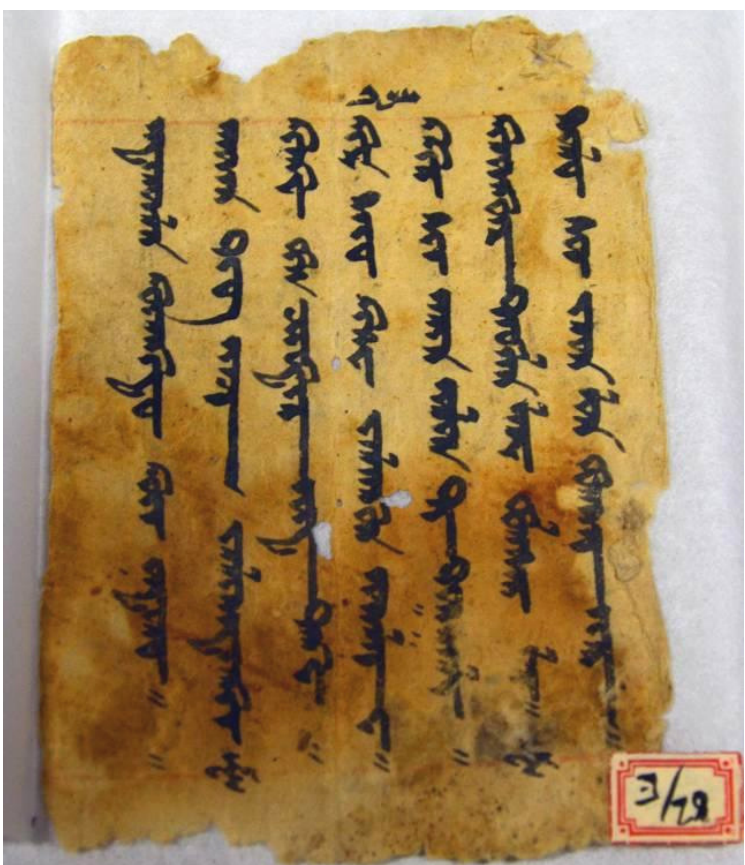

Figure 2. D.0019 (52.35.20). Verso 


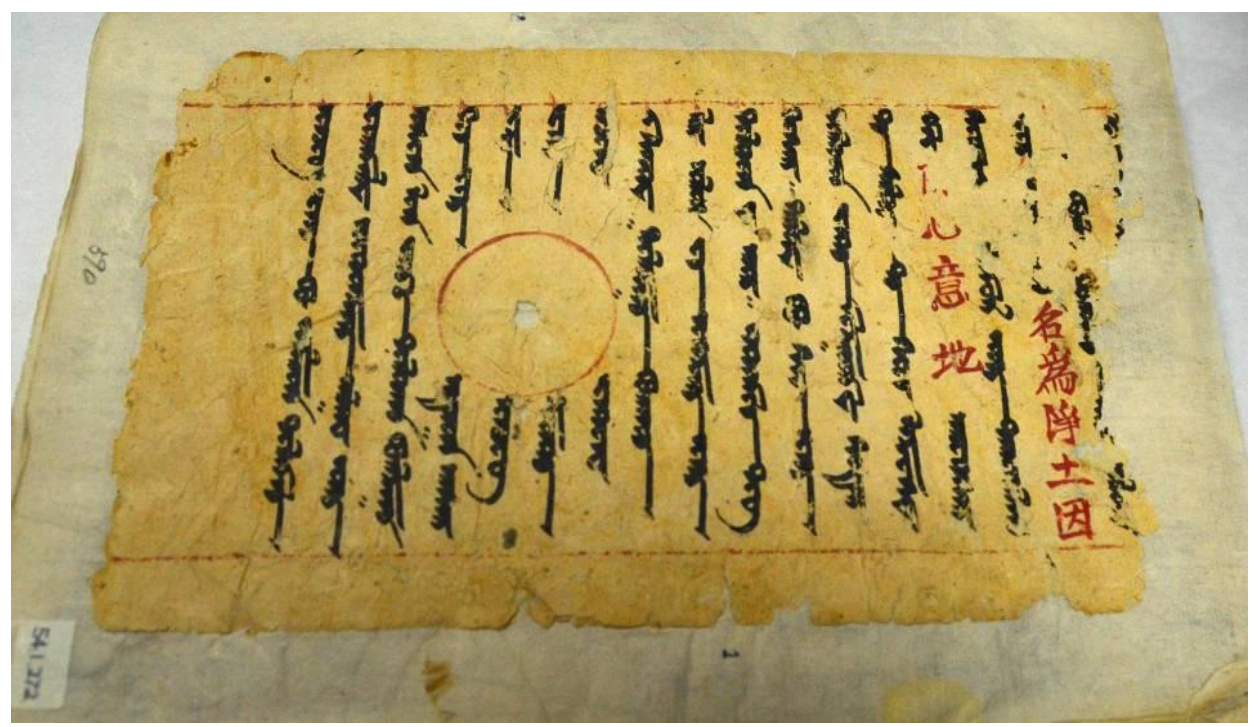

Figure 3. D.0590 (54.1.272) 
